\title{
Bacteria and fungi associated with abortion in sheep and goat in Menoufiea Governorate
}

By

\author{
Elham I. Atwa* and Flourage M. Rady ${ }^{* *}$ \\ *Bacteriology and ${ }^{* *}$ Mycology Department, Animal Health \\ Research Institute Shebin El- Kom-Menoufiea
}

\begin{abstract}
SUMMARY
A total of (120) samples of aborted foeti, vaginal discharage and Placenta were collected from (70) aborted ewes and (50) aborted she goats from Menoufiea Governorate for bacteriological and mycological examination. Swabs from stomach and intestinal contents of aborted foeti as well as liver, spleen, and lungs were collected. The bacteriological examination of aborted foeti, vaginal discharage and Placenta of aborted sheep revealed the isolation of Brucella melitensis, Campylobacter fetus subsp.fetus, Campylobacter fetus subsp.venerealis, Listeria monocytogens, Salmonella typhimurium, Salmonella dublin, Escherichia coli and Staph. aureus with the incidences of $21.4 \%$, $11.4 \%, 7.1 \%, 8.6 \%, 5.7 \%, 2.9 \%, 1.4 \%$ and $1.4 \%$, respectively. While the bacteria isolated from aborted she goats were Brucella melitensis, Campylobacter fetus subsp. fetus, Campylobacter fetus subsp.venerealis, Listeria monocytogens, Salmonella typhimurium, Salmonella dublin, Staph. aureus and Escherichia coli with the incidences of $20 \%, 10 \%, 6 \%, 10 \%, 8 \%$, $4 \%, 4 \%$ and $2 \%$, respectively.
\end{abstract}

Mycological examination of aborted foeti, vaginal discharage and Placenta of aborted sheep revealed the isolation of Aspergillus fumigatus, Aspergillus niger, Aspergillus flavus, Candida albicans, Candida krusei, Mucor spp. Abisidia spp. and Rhodotrula spp. with incidence of (12.9\%,5.7\%, 2.9\%, 8.6\%, $2.9 \%, 4.3 \%, 2.9 \%$ and $1.4 \%$, respectively). While the fungi isolated from aborted she goats were Aspergillus fumigatus, Aspergillus niger, Aspergillus flavus, Candida tropicalis, Candida albicans, Mucor spp., Rhizopus spp., Penicillium pp. and Fusarium spp. with incidence of $(14 \%, 6 \%, 2 \%, 10 \%, 8 \%$, $6 \%, 4 \%, 2 \%$ and $2 \%$, respectively).

The stomach contents of the aborted foeti of ewes and she goats were the most common seat for the isolation of bacteria and fungi which cause abortion

In vitro the antibiogram test indicated that the different bacterial species were more sensitive to danofloxacin, gentamicin, erythromycin and amoxicllin $\&$ clavulanic acid. While the most fungal isolates were sensitive to clotrimazole and miconazole. 
PCR (Polymerase chain reaction assay) was a valuable tool for direct and rapid diagnosis of Brucella melitiensis and Aspergillus fumigatus from aborted foeti specimens. The amplification of 169 and $792 \mathrm{bp}$ fragments from the extracted DNA of Brucella melitensis, while $383 \mathrm{bp}$ fragments from the extracted DNA of Aspergillus fumigatus were done.

\section{INTRODUCTION}

Sheep and goat represent an important sources of meat and milk production as human consumption in Egypt. High need of animal protein in Egypt increases year by year .So to overcome the problem of this deficiency, the maintenance of good fertility in herds is important because the reproductive health of animals is related to the nutritional needs of human population from meat, milk and wool for manufacturing purposes.

These large farms met various problem especially the abortion problem which is initiated through various causes. Abortion is caused by many factors as mechanicl, chemical, nutritional, bacterial and mycotic causes .

Bacterial abortion caused by Brucella melitiensis, Campylobacter fetus, Listeria monocytogens, Salmonella spp., Escherichia coli, Leptospira, Staph. aureus, Streptococci, Corynebacterium pyogens and Chlamydia spp. (Kholeaf et al., 1977 , Butachaiah and Khera ,1982 , Bajmocy et al., 1987, Plagemann, 1989 and Sargison et al.,2001).

Mycotic abortion caused by Aspergillus spp. Candida spp. Rhodotorula spp. Absidia spp., Alternaria spp. and Mucor spp. ( Pal et al., 1985, Pal, 1988 and Verma et al., 1999).

Brucellosis is a zoonotic disease that cause abortion, fetus death and genital infections in animals and humans. The illness initially presents as fever and may later affecting various organs and tissues (Redkar et al., 2001). Brucellosis is considered one of the major problem affecting sheep and goats, producing many economic losses due to abortion and infertality (Butachaiah and Khera, 1982 ). Sheep and goats are mainly affected by Brucella melitiensis ( Wilson and Miles, 1975).

Vibronic abortion of sheep and goat are characterized by abortion during the last half of gestation period, the disease is extermely sporadic. The incidence of abortion in sheep and goat occur due to Campylobacter fetus may reach up to 70\% ( Flaat and Roed, 1980, Bird et al., 1984, Bajmocy et al., 1987 and Varga, 1990) . While listeria monocytogens is a public health concern and affect human whose immune system are inefficient, and in pregnant women cause infant death, meningitis and abortion. In infected sheep and goats, abortion occurred at early stages of pregnancy and stillborn or weak kids (Plagemann ,1989). 
Fungi are pathogenic to man and animals, and are able to grow saprobiologically. They produce serious disease symptome as inflammation of the genitalia especially endometritis with mucopurulent discharge. They may be responsible for causing infertility, and abortion (Ainsworth and Austwick, 1973). Mycotic abortin is caused by fungal infection of the genital tract by several moulds and yeasts(Kirkbride, 1990 and Knudtson and Kirkbride, 1992). Abortion usually occurred during the last trimester of pregnancy (Williams et al.,1977 and Corbel,1988). The fungus Aspergillus fumigatus and Aspergillus niger were isolated in pure culture from cases of abortion in ewe by several researchers as ( Siddique et al., 1976, Cuci, 1987, Pal, 1988 , Vandyousefi \& Zoghi 1988 and Patnaik et al., 1992).

Mycotic abortion among ewes reflects its isolation for the first time in India. Aspergillus fumigatus from cases of metritis and abortion in cows (Pathak \& Mittal, 1966 and Pal et al., 1985). Mycotoxins in the genital tract are spermicidal to spermatozoa, as documented by Saxena and Ishaque (1977).

Identification of Brucella melitiensis and Aspergillus fumigatus by isolation was time consuming and the cultures need to be handled with care because of the zoonotic potential. So PCR assay was used for confirmation of presumptive Brucella melitiensis and Aspergillus fumigatus isolates, allowing the rapid diagnosis and facilitated studies of microorganisms (Brieker and Halling 1994, Cetinkaya et al., 1999, Liliana et al., 2004, William et al., 2004 and David et al., 2005).

The aim of this study is to prove the microbiological causes of sheep and goat abortion. This can be established through demonstration, isolation and identification of the bacterial and mycotic agents. On the other hand, their susceptibility to chemotherapeutic agents was done as an aid to overcome this problem and reduce losses. Also, using polymerase chain reaction (PCR) test to substitute the conventional cultural methods and rapid diagnosis of Brucella melitiensis and Aspergillus fumigatus.

\section{Samples:}

\section{MATERIAL AND METHODS}

120 samples of aborted foeti were obtained under complete aseptic condition from 70 ewes and 50 she goats for bacteriological and mycological examination. Swabs from all number of examined samples of stomach and intestinal contents of aborted foeti as well as liver, spleen, and lungs were collected in a separete sterile containers and were transported as quickly as possible to laboratory in ice box (Animal Health Research Institute - Shebin El-Kom ).

Placenta and vaginal discharage were collected aseptically from aborted ewes and she goats by sterile cotton swabs and tranferred immediately to the laboratory, where they were examined bacteriologically and mycologically. 
All samples were obtained from aborted ewes and she goats from various private farms at El- Menoufiea Governorate .

\section{Bacteriological examination:}

The collected samples including swabs from stomach (abomasal), intestinal contents, vaginal samples and placenta of the aborted foeti as well as internal organs were inoculated directly onto the Albimi agar plates, Cmpylobacter blood free selective agar, blood agar ,MacConkey's bile salt lactose agar, S.S. agar and mannitol salt agar. The inoculated plates for the Albimi agar plates was incubated in aerobic condition in jars or incubator containing 5-10\% $\mathrm{CO}_{2}$ at $37^{\circ} \mathrm{C}$. Cmpylobacter blood free selective agar supplemented with antibiotics was incubated in microaerophilic condition of reduced $5 \% \mathrm{O}_{2}, 10 \% \mathrm{CO}_{2}$ using $\mathrm{CO}_{2}$ generating kit and $85 \% \mathrm{~N}_{2}$ in plastic anaerobic jar at $37{ }^{\circ} \mathrm{C}$ for $3-4$ days . Then suspected Brucella colonies were identified morphologically, staining reactions and biochemically according to Alton et al., (1975). While Campylobacter colonies were identified according to Skirrow and Benjamin, (1980) and Prescott and Munroe, (1982).

The inoculated plates for the last four media were incubated at $37^{\circ} \mathrm{C}$ for $24-$ 48 hours, then suspected colonies were picked up and streaked onto nutrient agar slant, incubated at $37^{\circ} \mathrm{C}$ for 24 hours to obtain pure culture. Suspected colonies were identified morphologically, Gram's stain reactions and biochemically according to the Koneman et al., (1992) and Quinn et al., (2002).

\section{Mycological examination:}

The collected samples,(swabs from stomach (abomasal), intestinal contents, vaginal samples and placenta of the aborted foeti as well as internal organs) were inoculated onto the surface of Sabouraud's dexrose agar (SDA) containing $0.05 \%$ chlooramphenicol, and Candida agar (CA), the spot inoculation method was followed to culture fungi . Plates were inoculated at $25^{\circ} \mathrm{C}$ for a minimum period of 7 days. The inoculated plates were examined for fungal growth, texture, diffusable pigment and morphological descripiton according to Raper and Fennel, (1965), Carter and Cole, (1990) and Koneman et al., (1992).

\section{Susceptability of isolates to chemotheraputic agents :}

The standardized disc agar diffusion method was applied on a pure subcultures to detect the drug of choice against different bacteria isolated strains accordind to Finegold and Martin (1982). The results were interpretated according to Koneman et al., (1992).

While use of filter paper disks ( $3 \mathrm{~mm}$ in diameter) were used for preparation of antimycotic disc by soaked disk in $1 \mathrm{ml}$ of drug used and left to complete dryness. Disks from each drug were put in the plate and incubated at $25{ }^{\circ} \mathrm{C}$ for 2-3 days according to Colle et al., (1996). The results were interpretated according to Rippon (1988). 


\section{Extraction of Brucella melitiensis DNA according to Sambrook et al., (1989) and William et al., (2004):}

Five $\mathrm{ml}$ of trypticase soy broth were inoculated with bacterial strains at $37^{\circ} \mathrm{C}$ for $24-48$ hours. Spin $1.5 \mathrm{ml}$ of culture in microcentrifuge for 2 minutes until the compact pellet forms and the supernatant discarded. The pellet resuspended in 500ul of TE buffer (Tris-EDTA buffer). Then 50uL of 10\% SDS (Sodium dodocyle sulphate) and $3 \mathrm{mg} / \mathrm{ml}$ proteinase $\mathrm{K}$ to give final concentration of $100 \mathrm{ug} / \mathrm{ml}$ proteinase $\mathrm{K}$ in $0.5 \%$ SDS then mixed and incubated for 1 hour at $37{ }^{\circ} \mathrm{C}$. Then add $100 \mathrm{ul}$ of $5 \mathrm{M} \mathrm{NaCL}$ and mixed to remove cell wall debris, denaturated protein and polysaccharides complexes. While retaining of the nucelic in the solution. Add apprximately equal volume of chloroform/ isoamyl alcohol then mixed and spins 4 to 6 minutes in a microcentrifuge, the aqueous, viscous supernatant is put in microcentrifuge tube with equal volume phenol / chloroform / isoamyl alcohol, extracted thoroughly, and spin in a microcentrifuge for 5 minutes. The supernatant is put in fresh tube with 0.6 volume isopropanol was added to precipitate nucleic acid, the tube was shaked until the DNA precipitate, then pelleted by spinning at room temperature. DNA was washed with $70 \%$ ethanol to remove residual and respinned 5 minutes at room temperature repellet, then remove supernatant and dried pellet by lyophlizer. DNA pellet was redissolved in $100 \mathrm{ul}$ of TE buffer.

\section{Primers for Brucella melitiensis:}

Specific oligonuclotide multiplex primer assay designated by Brieker and Halling (1994) and Ewalt and Bricker (2000) as AMOS for rapid differenenation between (Abortus, Melitiensis, Ovis, Suis), The forward primer for Brucella melitiensis was (5'-AAA-TCG-CGT-CCT-TGC-TGG-TCT-GA$\left.3^{\prime}\right)$. While the IS711 was used as a reverse primer (5'-TGC-CGA-TCA-CTTAAG-GGC-CTT-CAT-3`). Specific primer for Brucella melitiensis was amplified fragment at:169bp and 792bp. The specific oligonuclotide primers were obtained from MWG Biotech AG and used as pooling primers for AMOS amplification.

\section{Brucella melitiensis DNA amplification by PCR:}

DNA samples were denaturated by boilling for 10 minutes before amplification and then quenched on ice. The PCR was performed according to Bricker and Halling (1994) in a touchdown thermocycler in a total reaction volume of $50 \mathrm{ul}$ containing $60 \mathrm{mM}$ tris- HCL (pH 9.0), $1.5 \mathrm{mM} \mathrm{MgCL}_{2}, 15 \mathrm{mM}$ $\left(\mathrm{NH}_{4}\right)_{2} \mathrm{SO}_{4}, 250 \mathrm{mM}$ each of the four deoxynucleotide triphosphate, $0.2 \mathrm{mM}$ of each primer, 1 unit of Taq polymerase and $200 \mathrm{uL}$ of extracted DNA. The PCR mixtures were over laid with $40 \mathrm{uL}$ paraffin oil and ampilified in DNA thermal cycler. Amplification was obtained with 35 cycles. Each cycle involved denaturation at $95^{\circ} \mathrm{C}$ for 1.5 minutes, annealing at $55{ }^{\circ} \mathrm{C}$ for 2 minutes, and extension at $72{ }^{\circ} \mathrm{C}$ for 2 minutes. The final extension was performed at $72^{\circ} \mathrm{C}$ for 5 minutes. 
For the detection PCR products, a $10 \mathrm{ul}$ of amplified DNA was examined by electrophoresis in $1.5 \%$ agarose gel, and visualized with ethidium bromide and UV light . Electrophoresis was carried out for 2 hours at $110 \mathrm{~V}$.

\section{Extraction of Aspergillus fumigatus DNA according to Liliana et al., (2004) and David et al., (2005):}

Aspergillus fumigatus was grown on $5 \mathrm{ml}$ sabourad dextrose agar in $50 \mathrm{ml}$ flask at $37{ }^{\circ} \mathrm{C}$ for 2 days and then left at $25^{\circ} \mathrm{C}$ to sporulate until mature. The agar was overlaid with $10 \mathrm{ml}$ of sterile $0.1 \%$ Tween 20 , then placed in rotary shaker for 10 minutes. The conidia and hyphal fragments of Aspergillus fumigatus was harvested and passed through 5um polycarbonate filter to remove hyphae.Stir bar was used to break hyphae by spinning on a stir plate.Hyphal fragments were pelleted by centrifugation at 3,200 x g for 15 minutes and resuspended in sterile water. The DNA was precipitated with isopropanol and sodium acetate, washed with $70 \%$ ethanol and resuspended in Tris-EDTA buffer. The extraction of DNA by (Ultra Clean soil DNA isolation kit) uses a bead matrix and lysis buffer to pulverize cells by horizontal shaking on a vortex mixer, followed by adsorpation of DNA to a spin filter, a wash step, and the dilution of DNA in TE buffer.

\section{Primers for Aspergillus fumigatus:}

Aspergillus fumigatus specific primer sequence were published by David $\boldsymbol{e t}$ al., (2005) the forward primer for PCR was Fun-18S-995F (5 '-CGA TYA GAT ACC GTY GTG TC-3'). While the Fun-18S-1217R was a reverse primer (5'TGT CTG GAC CTG GTG AGT TT-3'). Specific primer for Aspergillus fumigatus was amplified fragment on :383bp. The specific oligonuclotide primers were obtained from Invitrogen Corp., Carlsbad.

\section{Aspergillus fumigatus DNA amplification by PCR:}

$2 \mathrm{ul}$ of diluted DNA samples were mixed with $20 \mathrm{mM}$ tris- HCL, $50 \mathrm{mM}$ $\mathrm{KCl}, 1.5 \mathrm{mM} \mathrm{MgCL} 2,0.2 \mathrm{mM}$ each of the four deoxynucleotide triphosphate, $0.5 \mathrm{mM}$ of each primer and 0.5 unit of Taq DNA polymerase, in total volume of $20 \mathrm{uL}$. PCR ampilification conditions were 5 minutes of denaturation at $96^{\circ} \mathrm{C}$, followed by 40 cycles of $94^{\circ} \mathrm{C}$ for 30 seconds, $58^{\circ} \mathrm{C}$ for 30 seconds, and $72{ }^{\circ} \mathrm{C}$ for 30 seconds. The final extension step was performed at $72{ }^{\circ} \mathrm{C}$ for 15 minutes, (David et al., 2005).

\section{RESULTS}

Results in Table (1), show the bacterial and fungal isolates from aborted foeti, vaginal discharge and placenta of aborted ewe. Out of 70 samples, 42 samples $(60 \%)$ were positive for bacteriological isolates, while 29 samples $(41.4 \%)$ were positive for mycological isolates. 
The bacteria isolated from ewe aborted foeti were Brucella melitensis, Campylobacter fetus subsp. fetus, Campylobacter fetus subsp.venerealis, Listeria monocytogens and Salmonella typhimurium with incidence of ( $10 \%$, $7.1 \%, 4.3 \%, 4.3 \%$ and $2.9 \%$, respectively). While the bacteriological isolation from vaginal discharge were Brucella melitensis, Campylobacter fetus subsp. fetus, Campylobacter fetus subsp.venerealis, Listeria monocytogens, Salmonella typhimurium, Salmonella dublin and Escherichia coli with incidence of $(4.3 \%, 1.4 \%, 1.4 \%, 2.9 \%, 1.4 \%, 1.4 \%$, and $1.4 \%$ respectively). The bacteriological isolation from placenta were Brucella melitensis, Campylobacter fetus subsp. fetus, Campylobacter fetus subsp.venerealis, Listeria monocytogens, Salmonella typhimurium, Salmonella dublin and Staph. aureus with incidence of $(7.1 \%, 2.9 \%, 1.4 \%, 1.4 \%, 1.4 \%, 1.4 \%$ and $1.4 \%$, respectively).

The fungi isolated from ewe aborted foeti were Aspergillus fumigatus, Aspergillus niger, Candida albicans, Mucor spp. and Abisidia spp. with incidence of $(8.6 \%, 1.4 \%, 4.3 \%, 2.9 \%$ and $1.4 \%$, respectively).The fungi isolated from vaginal discharge were Aspergillus fumigatus, Aspergillus niger, Aspergillus flavus, Candida albicans, Candida krusei, Mucor spp. Abisidia spp. and Rhodotrula spp. with incidence of $(2.9 \%, 1.4 \%, 1.4 \%, 2.9 \%, 1.4 \%$, $1.4 \%, 1.4 \%$ and $1.4 \%$, respectively). While the fungi isolated from placenta were Aspergillus fumigatus, Aspergillus niger, Candida albicans and Candida krusei with incidence of $(1.4 \%, 1.4 \%, 1.4 \%$ and $1.4 \%$, respectively).

In attempt to correlate the relation between various types of bacteria and fungi and their sites of positive aborted ewe foeti, the data obtained were recorded in Table (2).Out of 20 aborted ewe infected with Brucella melitensis, Campylobacter fetus subsp. fetus, Campylobacter fetus subsp.venerealis, Listeria monocytogens and Salmonella typhimurium the organisms were present mainaly in the fourth stomach cotents with incidence of $100 \%$ in all bacterial isolates, then marked drop in liver with an incidence of $(85.7 \%$, $80 \%, 100 \%, 66.7 \%$, and $100 \%$, respectively), followed by spleen with an incidence of $(85.7 \%, 60 \%, 66.7 \%, 66.7 \%$ and $50 \%$, respectively).Also lung specimens were the least common seats of infection with an incidence of (71.4\%, 60\%, 66.7\%, $0 \%$, and $50 \%$, respectively) .

While Out of 14 aborted ewe infected with Aspergillus fumigatus, Aspergillus niger, Candida albicans, Mucor spp. and Abisidia spp. The fungi were present mainaly in the fourth stomach cotents with incidence of $100 \%$ in all fungal isolates, then marked drop in lungs with an incidence of $(100 \%, 50 \%$, $66.7 \%, 100 \%$ and $100 \%$, respectively), followed by liver with an incidence of $(83.3 \%, 100 \%, 66.7 \%, 50 \%$ and $0 \%$, respectively). Also spleen specimens were the least common seats of infection with an incidence of $(66.7 \%, 50 \%, 33.3 \%$, $0 \%$ and $0 \%$, respectively) .

Results in Table (3), show the bacterial and fungal isolates from aborted foeti, vaginal discharge and placenta of aborted goats.Out of 50 samples,32 
samples(64\%) were positive for bacteriological isolates, while 27 samples $(54 \%)$ were positive for mycological isolates.

The bacteria isolated from goat aborted foeti were Brucella melitensis, Campylobacter fetus subsp. fetus, Campylobacter fetus subsp.venerealis, Listeria monocytogens, Salmonella typhimurium, Salmonella dublin and Staph. aureus with incidence of $(12 \%, 6 \%, 2 \%, 4 \%, 4 \%, 2 \%$ and $2 \%$, respectively). While the bacteriological isolation from vaginal discharge were Brucella melitensis, Campylobacter fetus subsp. fetus, Campylobacter fetus subsp.venerealis, Listeria monocytogens, Salmonella typhimurium, Salmonella dublin and Escherichia coli with incidence of ( 4\%, 2\%, 2\%, 2\%, 2\%, 2\%, 2\% and $2 \%$ respectively). The bacteriological isolation from placenta were Brucella melitensis, Campylobacter fetus subsp. fetus, Campylobacter fetus subsp.venerealis, Listeria monocytogens, Salmonella typhimurium and Staph. aureus with incidence of $(4 \%, 2 \%, 2 \%, 4 \%, 2 \%$ and $2 \%$, respectively).

The fungi isolated from ewe aborted foeti of goats were Aspergillus fumigatus, Aspergillus niger, Candida tropicalis, Candida albicans, Mucor spp. and Rhizopus spp. with incidence of $(8 \%, 4 \%, 4 \%, 2 \%, 2 \%$ and $2 \%$, respectively).The fungi isolated from vaginal discharge were Aspergillus fumigatus, Aspergillus niger, Aspergillus flavus, Candida tropicalis, Candida albicans, Mucor spp., Rhizopus spp., Penicillium pp. and Fusarium spp. with incidence of $(4 \%, 2 \%, 2 \%, 2 \%, 2 \%, 2 \%, 2 \%, 2 \%$ and $2 \%$, respectively). While the fungi isolated from placenta were Aspergillus fumigatus, Candida tropicalis, Candida albicans and Mucor Spp. with incidence of $(2 \%, 4 \%, 2 \%$ and $2 \%$, respectively).

In attempt to correlate the relation between various types of bacteria and fungi and their sites of positive aborted ewe foeti, the data obtained were recorded in Table (4).Out of 16 aborted goat infected with Brucella melitensis, Campylobacter fetus subsp. fetus, Campylobacter fetus subsp. venerealis, Listeria monocytogens, Salmonella typhimurium, Salmonella dublin and Staph. aureus the organisms were present mainaly in the fourth stomach cotents with incidence of $100 \%$ in all bacterial isolates, then marked drop in liver with an incidence of $(66.7 \%, 66.7 \%, 100 \%, 50 \%, 100 \%, 100 \%$ and $0 \%$, respectively), followed by spleen with an incidence of $(83.3 \%, 33.3 \%, 0 \%, 50 \%, 50 \%, 0 \%$ and $0 \%$, respectively).Also lung specimens were the least common seats of infection with an incidence of $(33.3 \%, 33.3 \%, 0 \%, 0 \%, 50 \%, 0 \%$ and $100 \%$, respectively) .

While Out of 14 aborted ewe infected with Aspergillus fumigatus, Aspergillus niger, Candida tropicalis, Candida albicans, Mucor spp. and Rhizopus spp. The fungi were present mainaly in the fourth stomach cotents with incidence of $100 \%$ in all fungal isolates, then marked drop in lungs with an incidence of $(100 \%, 50 \%, 100 \%, 100 \%, 0 \%$ and $100 \%$, respectively), followed by liver with an incidence of $(75 \%, 50 \%, 50 \%, 50 \%, 0 \%$ and $0 \%$, 
respectively).Also spleen specimens were common seats of infection with an incidence of $(100 \%, 100 \%, 100 \%, 50 \%, 100 \%$ and $0 \%$, respectively) .

Table (5) : show the results of the antibiogram of different isolates in which gentamicin, danofloxacin and erythromycin were the most effective anti bacterials on the Campylobacter fetus subsp.fetus, while danofloxacin, amoxicllin\& clavulanic acid, erythromycin and lincomycin were the most effective anti bacterials on the Campylobacter fetus subsp venerealis, but amoxicllin\& clavulanic acid, cephalocin, danofloxacin, penicillin $G$ and chloramphenicol were the most effective anti bacterials on the Listeria monocytogens. Salmonella spp was sensitive to danofloxacin, gentamicin and chloramphenicol, but Staph. aureus isolates were sensitive to amoxicllin\& clavulanic acid, cephalocin and danofloxacin, while E. coli was sensitive to amoxicllin\& clavulanic acid, danofloxacin and penicillin $\mathrm{G}$.

Table(6):summarized the results of chemical compounds were tested as antifungal agents, in which Aspergillus fumigatus and Aspergillus flavus were highly sensitive to anti fungal agents clotrimazole (canesten) and miconazole, intermediate in sensitivity to nystatin and resistant to thibenzole. While Aspergillus niger were highly sensitive to clotrimazole (canesten) and miconazole, but resistant to nystatin and thibenzole. All tested strains of Candida albicans and Candida krusei completely resistant to nystatin and miconazole, but highly sensitive to clotrimazole and thibenzole. Meanwhile Candida tropicalis were highly senstitive to clotrimazole, intermediate in sensitivity to thibenzole, but resistant to nystatin and miconazole.

Two isolates representative of Brucella melitensis and two isolates for Aspergillus fumigatus were selected and subjected to PCR analysis. The specificity of the oligonucleotide primer was confrimed by the positive amplification of 169 and $792 \mathrm{bp}$ fragments from the extracted DNA of Brucella melitensis, while $383 \mathrm{bp}$ fragments from the extracted DNA of Aspergillus fumigatus (Fig.1). 
Table (1):Prevalence of bacteria and fungi isolated from vaginal discharge, placenta and aborted foeti of aborted sheep.

\begin{tabular}{|c|c|c|c|c|c|c|c|c|}
\hline \multirow{3}{*}{$\begin{array}{l}\text { Microorganisms } \\
\text { A-Bacterial isolates }\end{array}$} & \multicolumn{6}{|c|}{ Sites of isolation } & \multirow{2}{*}{\multicolumn{2}{|c|}{$\begin{array}{c}\text { Total } \\
\text { isolates }\end{array}$}} \\
\hline & \multicolumn{2}{|c|}{$\begin{array}{l}\text { Aborted } \\
\text { foeti (70) }\end{array}$} & \multicolumn{2}{|c|}{$\begin{array}{c}\text { Vaginal } \\
\text { discharge }(70)^{*}\end{array}$} & \multicolumn{2}{|c|}{$\begin{array}{c}\text { Placenta } \\
(70)^{*}\end{array}$} & & \\
\hline & No. & $\%$ & No. & $\%$ & No. & $\%$ & No. & $\%$ \\
\hline Brucella melitensis & 7 & 10 & 3 & 4.3 & 5 & 7.1 & 15 & 21.4 \\
\hline C. fetus subsp. fetus & 5 & 7.1 & 1 & 1.4 & 2 & 2.9 & 8 & 11.4 \\
\hline C. fetus subsp. venerealis & 3 & 4.3 & 1 & 1.4 & 1 & 1.4 & 5 & 7.1 \\
\hline Listeria monocytogens & 3 & 4.3 & 2 & 2.9 & 1 & 1.4 & 6 & 8.6 \\
\hline Salmonella typhimurium & 2 & 2.9 & 1 & 1.4 & 1 & 1.4 & 4 & 5.7 \\
\hline Salmonella dublin & 0 & 0 & 1 & 1.4 & 1 & 1.4 & 2 & 2.9 \\
\hline Escherichia coli & 0 & 0 & 1 & 1.4 & 0 & 0 & 1 & 1.4 \\
\hline Staph. aureus & 0 & 0 & 0 & 0 & 1 & 1.4 & 1 & 1.4 \\
\hline Total bacterial isolates & 20 & 28.6 & 10 & 14.3 & 12 & 17.1 & 42 & 60 \\
\hline \multicolumn{9}{|l|}{ B-Fungus isolates } \\
\hline Aspergillus fumigatus & 6 & 8.6 & 2 & 2.9 & 1 & 1.4 & 9 & 12.9 \\
\hline Aspergillus niger & 2 & 1.4 & 1 & 1.4 & 1 & 1.4 & 4 & 5.7 \\
\hline Aspergillus flavus & 0 & 0 & 1 & 1.4 & 0 & 0 & 2 & 2.9 \\
\hline Candida albicans & 3 & 4.3 & 2 & 2.9 & 1 & 1.4 & 6 & 8.6 \\
\hline Candida krusei & 0 & 0 & 1 & 1.4 & 1 & 1.4 & 2 & 2.9 \\
\hline Mucor species & 2 & 2.9 & 1 & 1.4 & 0 & 0 & 3 & 4.3 \\
\hline Abisidia species & 1 & 1.4 & 1 & 1.4 & 0 & 0 & 2 & 2.9 \\
\hline Rhodotrula species & 0 & 0 & 1 & 1.4 & 0 & 0 & 1 & 1.4 \\
\hline Total fungal isolates & 14 & 20 & 11 & 15.7 & 4 & 5.7 & 29 & 41.4 \\
\hline
\end{tabular}

* Number of examined samples

Table (2): Bacteria and fungi isolated from aborted sheep foeti as regarded to its sites of isolation from the internal organs.

\begin{tabular}{|c|c|c|c|c|c|c|c|c|c|c|}
\hline \multirow{3}{*}{$\begin{array}{c}\text { Microorganisms } \\
\text { A-Bacterial isolates }\end{array}$} & \multirow{2}{*}{\multicolumn{2}{|c|}{$\begin{array}{c}\text { Total } \\
\text { isolates }\end{array}$}} & \multicolumn{8}{|c|}{ Sites of isolation } \\
\hline & & & \multicolumn{2}{|c|}{$\begin{array}{c}\text { Stomach } \\
\text { content }\end{array}$} & \multicolumn{2}{|c|}{ Liver } & \multicolumn{2}{|c|}{ Spleen } & \multicolumn{2}{|c|}{ Lungs } \\
\hline & No. & $\%$ & No. & $\%$ & No. & $\%$ & No. & $\%$ & No. & $\%$ \\
\hline Brucella melitensis & 7 & 10 & 7 & 100 & 6 & 85.7 & 6 & 85.7 & 5 & 71.4 \\
\hline C. fetus subsp. fetus & 5 & 7.1 & 5 & 100 & 4 & 80 & 3 & 60 & 3 & 60 \\
\hline C. fetus subsp.venerealis & 3 & 4.3 & 3 & 100 & 3 & 100 & 2 & 66.7 & 2 & 66.7 \\
\hline Listeria monocytogens & 3 & 4.3 & 3 & 100 & 2 & 66.7 & 2 & 66.7 & 0 & 0 \\
\hline Salmonella typhimurium & 2 & 2.9 & 2 & 100 & 2 & 100 & 1 & 50 & 1 & 50 \\
\hline Total bacterial isolates & 20 & 28.6 & 20 & 100 & 17 & 85 & 14 & 70 & 11 & 55 \\
\hline \multicolumn{11}{|l|}{ B-Fungus isolates } \\
\hline Aspergillus fumigatus & 6 & 8.6 & 6 & 100 & 5 & 83.3 & 4 & 66.7 & 6 & 100 \\
\hline Aspergillus niger & 2 & 1.4 & 2 & 100 & 2 & 100 & 1 & 50 & 1 & 50 \\
\hline Candida albicans & 3 & 4.3 & 3 & 100 & 2 & 66.7 & 1 & 33.3 & 2 & 66.7 \\
\hline Mucor species & 2 & 2.9 & 2 & 100 & 1 & 50 & 0 & 0 & 2 & 100 \\
\hline Absidia species & 1 & 1.4 & 1 & 100 & 0 & 0 & 0 & 0 & 1 & 100 \\
\hline Total fungal isolates & 14 & 20 & 14 & 100 & 10 & 71.4 & 6 & 42.9 & 12 & 85.7 \\
\hline
\end{tabular}


Table (3):Prevalence of bacteria and fungi isolated from vaginal discharge, placenta and aborted foeti of aborted goats.

\begin{tabular}{|c|c|c|c|c|c|c|c|c|}
\hline \multirow{3}{*}{$\begin{array}{l}\text { Microorganisms } \\
\text { A-Bacterial isolates }\end{array}$} & \multicolumn{6}{|c|}{$\begin{array}{l}\text { Sites of isolation } \\
\end{array}$} & \multirow{2}{*}{\multicolumn{2}{|c|}{$\begin{array}{c}\text { Total } \\
\text { isolates }\end{array}$}} \\
\hline & \multicolumn{2}{|c|}{$\begin{array}{c}\text { Aborted } \\
\text { foeti(50)* }\end{array}$} & \multicolumn{2}{|c|}{$\begin{array}{c}\text { Vaginal } \\
\text { discharge }(50)^{*}\end{array}$} & \multicolumn{2}{|c|}{$\begin{array}{l}\text { Placenta } \\
(\mathbf{5 0})^{*}\end{array}$} & & \\
\hline & No. & $\%$ & No. & $\%$ & No. & $\%$ & No. & $\%$ \\
\hline Brucella melitensis & 6 & 12 & 2 & 4 & 2 & 4 & 10 & 20 \\
\hline C. fetus subsp. fetus & 3 & 6 & 1 & 2 & 1 & 2 & 5 & 10 \\
\hline C. fetus subsp. venerealis & 1 & 2 & 1 & 2 & 1 & 2 & 3 & 6 \\
\hline Listeria monocytogens & 2 & 4 & 1 & 2 & 2 & 4 & 5 & 10 \\
\hline Salmonella typhimurium & 2 & 4 & 1 & 2 & 1 & 2 & 4 & 8 \\
\hline Salmonella dublin & 1 & 2 & 1 & 2 & 0 & 0 & 2 & 4 \\
\hline Staph. aureus & 1 & 2 & 0 & 0 & 1 & 2 & 2 & 4 \\
\hline Escherichia coli & 0 & 0 & 1 & 2 & 0 & 0 & 1 & 2 \\
\hline Total bacterial isolates & 16 & 32 & 8 & 16 & 8 & 16 & 32 & 64 \\
\hline \multicolumn{9}{|l|}{ B-Fungus isolates } \\
\hline Aspergillus fumigatus & 4 & 8 & 2 & 4 & 1 & 2 & 7 & 14 \\
\hline Aspergillus niger & 2 & 4 & 1 & 2 & 0 & 0 & 3 & 6 \\
\hline Aspergillus flavus & 0 & 0 & 1 & 2 & 0 & 0 & 1 & 2 \\
\hline Candida tropicalis & 2 & 4 & 1 & 2 & 2 & 4 & 5 & 10 \\
\hline Candida albicans & 2 & 2 & 1 & 2 & 1 & 2 & 4 & 8 \\
\hline Mucor species & 1 & 2 & 1 & 2 & 1 & 2 & 3 & 6 \\
\hline Rhizopus species & 1 & 2 & 1 & 2 & 0 & 0 & 2 & 4 \\
\hline Penicillium species & 0 & 0 & 1 & 2 & 0 & 0 & 1 & 2 \\
\hline Fusarium species & 0 & 0 & 1 & 2 & 0 & 0 & 1 & 2 \\
\hline Total fungal isolates & 12 & 24 & 10 & 20 & 5 & 10 & 27 & 54 \\
\hline
\end{tabular}

* Number of examined samples

Table (4): Bacteria and fungi isolated from aborted goats foeti as regarded to its sites of isolation from the internal organs.

\begin{tabular}{|c|c|c|c|c|c|c|c|c|c|c|}
\hline \multirow{3}{*}{$\begin{array}{c}\text { Microorganisms } \\
\text { A-Bacterial isolates }\end{array}$} & \multirow{2}{*}{\multicolumn{2}{|c|}{$\begin{array}{c}\text { Total } \\
\text { isolates }\end{array}$}} & \multicolumn{8}{|c|}{ Sites of isolation } \\
\hline & & & \multicolumn{2}{|c|}{$\begin{array}{c}\text { Stomach } \\
\text { content }\end{array}$} & \multicolumn{2}{|c|}{ Liver } & \multicolumn{2}{|c|}{ Spleen } & \multicolumn{2}{|c|}{ Lungs } \\
\hline & No. & $\%$ & No. & $\%$ & No. & $\%$ & No. & $\%$ & No. & $\%$ \\
\hline Brucella melitensis & 6 & 12 & 6 & 100 & 4 & 66.7 & 5 & 83.3 & 2 & 33.3 \\
\hline C. fetus subsp. fetus & 3 & 6 & 3 & 100 & 2 & 66.7 & 1 & 33.3 & 1 & 33.3 \\
\hline C. fetus subsp.venerealis & 1 & 2 & 1 & 100 & 1 & 100 & 0 & 0 & 0 & 0 \\
\hline Listeria monocytogens & 2 & 4 & 2 & 100 & 1 & 50 & 1 & 50 & 0 & 0 \\
\hline Salmonella typhimurium & 2 & 4 & 2 & 100 & 2 & 100 & 1 & 50 & 1 & 50 \\
\hline Salmonella dublin & 1 & 2 & 1 & 100 & 1 & 100 & 0 & 0 & 0 & 0 \\
\hline Staph. aureus & 1 & 2 & 1 & 100 & 0 & 0 & 0 & 0 & 1 & 100 \\
\hline Total bacterial isolates & 16 & 32 & 16 & 100 & 11 & 64.7 & 8 & 47.1 & 5 & 29.4 \\
\hline \multicolumn{11}{|l|}{ B-Fungus isolates } \\
\hline Aspergillus fumigatus & 4 & 8 & 4 & 100 & 4 & 100 & 3 & 75 & 4 & 100 \\
\hline Aspergillus niger & 2 & 4 & 2 & 100 & 1 & 50 & 1 & 50 & 2 & 100 \\
\hline Candida tropicalis & 2 & 4 & 2 & 100 & 2 & 100 & 1 & 50 & 2 & 100 \\
\hline Candida albicans & 2 & 2 & 2 & 100 & 2 & 100 & 1 & 50 & 1 & 50 \\
\hline Mucor species & 1 & 2 & 1 & 100 & 0 & 0 & 0 & 0 & 1 & 100 \\
\hline Rhizopus species & 1 & 2 & 1 & 100 & 1 & 100 & 0 & 0 & 0 & 0 \\
\hline Total fungal isolates & 12 & 24 & 12 & 100 & 10 & 83.3 & 6 & 50 & 10 & 83.3 \\
\hline
\end{tabular}


Table (5) :Antibiotic sensitivity test of the different isolated strains isolated from aborted sheep and goats using disc diffusion method.

\begin{tabular}{|c|c|c|c|c|c|c|c|c|c|c|c|c|c|}
\hline \multirow[t]{2}{*}{$\begin{array}{l}\text { Antibacterial } \\
\text { agents }\end{array}$} & \multirow[t]{2}{*}{ Concentration } & \multicolumn{2}{|c|}{$\begin{array}{c}\text { C.fetus } \\
\text { supsp. fetus } \\
\text { (13) }\end{array}$} & \multicolumn{2}{|c|}{$\begin{array}{c}\text { C.fetus } \\
\text { supsp. } \\
\text { Venerealis } \\
(8)^{*}\end{array}$} & \multicolumn{2}{|c|}{$\begin{array}{c}\text { Listeria } \\
\text { monocytogens } \\
(11)^{*}\end{array}$} & \multicolumn{2}{|c|}{$\begin{array}{l}\text { Salmonella } \\
\text { spp. (12) }\end{array}$} & \multicolumn{2}{|c|}{$\begin{array}{c}\text { Staph. } \\
\text { aureus (3) }\end{array}$} & \multicolumn{2}{|c|}{ E.coli (2) } \\
\hline & & S. & $\%$ & S. & $\%$ & S. & $\%$ & $S$. & $\%$ & S. & $\%$ & S. & $\%$ \\
\hline Ampicillin & 10ug & $3 / 13$ & 23.1 & $3 / 8$ & 37.5 & $10 / 11$ & & $1 / 12$ & & $2 / 3$ & 66.7 & $1 / 2$ & 50 \\
\hline $\begin{array}{c}\text { Amoxicillin }+ \\
\text { Clavulanic acid }\end{array}$ & 10ug & $8 / 13$ & 61.5 & $6 / 8$ & 75 & $11 / 11$ & 100 & $4 / 12$ & 33.3 & $3 / 3$ & 100 & $2 / 2$ & 100 \\
\hline Cephalocin & & $1 / 13$ & 7.7 & $0 / 8$ & 0 & $11 / 11$ & 100 & $6 / 12$ & 50 & $3 / 3$ & 100 & $1 / 2$ & 50 \\
\hline Chloramphenicol & 30ug & $0 / 13$ & 0 & $0 / 8$ & 0 & $9 / 11$ & 81.8 & $10 / 12$ & 83.3 & $1 / 3$ & 33.3 & $1 / 2$ & 50 \\
\hline Danofloxacin & 30ug & $13 / 13$ & 100 & $8 / 8$ & 100 & $10 / 11$ & 90.9 & $12 / 12$ & 100 & $3 / 3$ & 100 & $2 / 2$ & 100 \\
\hline Erythromycin & $10 \mathrm{ug}$ & $11 / 13$ & 84.6 & $6 / 8$ & 75 & $5 / 11$ & 45.5 & $3 / 12$ & 25 & $1 / 3$ & 33.3 & $0 / 2$ & 0 \\
\hline Gentamicin & 10ug & $13 / 13$ & 100 & $4 / 8$ & 50 & $3 / 11$ & 27.3 & $11 / 12$ & 91.7 & $2 / 3$ & 66.7 & $0 / 2$ & 0 \\
\hline Lincomycin & $10 \mathrm{ug}$ & $3 / 13$ & 23.1 & $6 / 8$ & 75 & $6 / 11$ & 54.5 & $7 / 12$ & 58.3 & $1 / 3$ & 33.3 & $0 / 2$ & 0 \\
\hline Neomycin & 30ug & $2 / 13$ & 15.4 & $5 / 8$ & 62.5 & $2 / 11$ & 18.2 & $7 / 12$ & 58.3 & $0 / 3$ & 0 & $0 / 2$ & 0 \\
\hline Oxytetracycline & $30 \mathrm{ug}$ & $3 / 13$ & 23.1 & $4 / 8$ & 50 & $8 / 11$ & 72.7 & $8 / 12$ & 66.7 & $0 / 3$ & 0 & $0 / 2$ & 0 \\
\hline Penicillin G & $10 \mathrm{U}$ & $2 / 13$ & 15.3 & $1 / 8$ & 12.5 & $10 / 11$ & 90.9 & $0 / 12$ & 0 & $1 / 3$ & 33.3 & $2 / 2$ & 100 \\
\hline Streptomycin & 10ug & $0 / 13$ & 0 & $0 / 8$ & 0 & $7 / 11$ & 63.6 & $2 / 12$ & 16.7 & $1 / 3$ & 33.3 & $0 / 2$ & 0 \\
\hline Tetracycline & $30 u g$ & $2 / 13$ & 15.4 & $2 / 8$ & 25 & $7 / 11$ & 63.6 & $6 / 12$ & 50 & $0 / 3$ & 0 & $1 / 2$ & 50 \\
\hline Trimethoprim & $1.25 \mathrm{ug}$ & $6 / 13$ & 46.2 & $4 / 8$ & 50 & $4 / 11$ & 36.4 & $8 / 12$ & 66.7 & $2 / 3$ & 66.7 & $1 / 2$ & 50 \\
\hline
\end{tabular}

*: Number of isolates.

S: Sensitive.

$\%$ : Percentage of sensitive isolates in relation to total isolates.

Table (6) :Antifungal sensitivity tests of the fungi isolated from aborted sheep and goats.

\begin{tabular}{|c|c|c|c|c|c|c|c|c|c|c|c|c|c|}
\hline \multirow[t]{2}{*}{$\begin{array}{l}\text { Antimycotic } \\
\text { agents }\end{array}$} & \multirow[t]{2}{*}{ Concentration } & \multicolumn{2}{|c|}{$\begin{array}{c}\text { Aspergillus } \\
\text { fumigatus }^{*} \\
{(16)^{*}}^{*}\end{array}$} & \multicolumn{2}{|c|}{$\begin{array}{c}\text { Aspergillus } \\
\text { niger (7) }\end{array}$} & \multicolumn{2}{|c|}{$\begin{array}{l}\text { Aspergillus } \\
\text { flavus (3) }^{*}\end{array}$} & \multicolumn{2}{|c|}{$\begin{array}{c}\text { Candida } \\
\text { albicans } \\
(10)^{*}\end{array}$} & \multicolumn{2}{|c|}{$\begin{array}{c}\text { Candida } \\
\text { tropicalis } \\
(5)^{*}\end{array}$} & \multicolumn{2}{|c|}{$\begin{array}{c}\text { Candida } \\
\text { krusei } \\
(2)^{*}\end{array}$} \\
\hline & & S. & $\%$ & S. & $\%$ & S. & $\%$ & $S$. & $\%$ & S. & $\%$ & S. & $\%$ \\
\hline $\begin{array}{c}\text { Nystatin } \\
\text { (mycostatin) }\end{array}$ & 1.000 unit & $10 / 16$ & 62.5 & $1 / 7$ & 14.3 & $2 / 3$ & 66.7 & $1 / 10$ & 10 & $0 / 5$ & 0 & $0 / 2$ & 0 \\
\hline $\begin{array}{c}\text { Miconazole } \\
\text { (Daktarin) }\end{array}$ & $0.2 \mathrm{mg}$ & $16 / 16$ & 100 & $7 / 7$ & 100 & $3 / 3$ & 100 & $3 / 10$ & 30 & $2 / 5$ & 40 & $1 / 2$ & 50 \\
\hline $\begin{array}{c}\text { Clotrimazole } \\
\text { (canesten) }\end{array}$ & $0.1 \mathrm{mg}$ & $14 / 16$ & 87.5 & $6 / 7$ & 85.7 & $3 / 3$ & 100 & $10 / 10$ & 100 & $4 / 5$ & 80 & $2 / 2$ & $\begin{array}{c}10 \\
0\end{array}$ \\
\hline $\begin{array}{c}\text { Thibenzole } \\
\text { (thiobendazole) }\end{array}$ & $10 \mathrm{mg}$ & $3 / 16$ & 18.75 & $2 / 7$ & 28.6 & $0 / 3$ & 0 & $7 / 10$ & 70 & $3 / 5$ & 60 & $2 / 2$ & $\begin{array}{c}10 \\
0\end{array}$ \\
\hline
\end{tabular}

*: Number of isolates.

S: Sensitive.

$\%$ : Percentage of sensitive isolates in relation to total isolates. 




Fig.(1): Electrophoresis analysis of PCR product of amplified Brucella melitensis and Aspergillus fumigatus.

$\mathrm{M}: 100 \mathrm{bp}$ marker.

Lane 1,2 indicate a positive amplification of Brucella melitensis at the 169 and $792 \mathrm{bp}$. Lane 3,4 indicate positive amplification of Aspergillus fumigatus at the $383 \mathrm{bp}$. 


\section{DISCUSSION}

Abortion of sheep and goats constitute the most importante problem causes a great economic implications in terms of milk yield, meat production and fertility of animals.

Bacteria and fungi were usually associated with abortion of sheep and goats. In this study, the bacteriological and mycological examination of aborted foeti, vaginal discharge and placenta of (70)aborted sheep revealed that 42 samples were $(60 \%)$ positive for bacteriological isolates, while 29 samples $(41.4 \%)$ were positive for mycological isolates.

As shown in Table (1), the bacteriological examination illusterated that the Brucella melitensis was the most microorganism isolated from aborted sheep with the incidence of $21.4 \%$. They mostly isolated from aborted foeti, placenta and vaginal discharge with the incidence of $(10 \%, 7.1 \%$ and $4.3 \%$, respectively from sheep),followed by Campylobacter fetus subsp. fetus, Campylobacter featus subsp.venerealis with the incidence of $11.4 \%$ and $7.1 \%$, respectively in sheep. Also Listeria monocytogens, Salmonella typhimurium, Salmonella dublin, Escherichia coli and Staph.aureus were isolated from aborted foeti, placenta and vaginal discharge with an incidence $8.6 \%, 5.7 \%, 2.9 \%, 1.4 \%$ and $1.4 \%$, respectively from sheep.These results agreement with Redman et al., (1963) who isolated campylobacter organisms with incidence of $14.7 \%$ from aborted ewe, Varga et al., (1990) recorded that abortion in sheep was caused in 18 flocks (78.3\%) by C. fetus subsp. fetus and in 5 flocks (21.7\%) by C. fetus subsp venerealis. Also agreement with Derbala and Ghazi (2001) they isolated Brucella melitensis from aborted sheep with the incidence of $18.9 \%$, Leyla et al., (2003) who identifed Brucella melitensis from aborted featus with an incidence of 31\%. While Plagemann (1989) isolated Listeria monocytogens, Salmonella typhimurium and Escherichia coli from aborted fetuse and placenta of aborted sheep Sargison et al., (2001) isolated E. coli from placenta of aborted sheep .

The mycological examination of aborted sheep as shown un table (1) illusterated that Aspergillus fumigatus was the most isolates among Aspergillus species with the incidence of $12.9 \%$. These results agreement with Siddique $\boldsymbol{e t}$ al., (1976), Cuci (1987), Vandyousefi and Zoghi (1988) and Munoz et al., (1989) they isolated Aspergillus fumigatus in a pure culture from cases of metritis and abortion in ewe. Candida albicans $(8.6 \%)$, was the $2^{\text {nd }}$ isolated fungus and this is in agreement with Osman and Abou-Gabal, (1978) who isolated Aspergillus fumigatus and Candida albicans from vaginal swabs of reproductive disorder ewes, while Faried et al., (1986) reported isolation of $42.8 \%$ of infertile ewe. Aspergillus niger, Aspergillus flavus, Mucor spp. Abisidia spp. and Rhodotrula spp. were isolated with the incidence of $(5.7 \%$, $2.9 \%, 2.9 \%, 4.3 \%, 2.9 \%$ and $1.4 \%$, respectively from aborted foeti, vaginal discharge and placenta of aborted sheep. This results runs parallel with Verma 
et al., (1999) who islated Aspergillus fumigatus, Aspergillus niger and Aspergillus flavus from aborted ewe and endometritis.

Specimens required for laboratory diagnosis of ovine abortions are abomasal contents, liver, spleen and lungs after fetal death. Clarifying the role of bacteria and fungi in aborted foetus may lead to more extensive light involving its problem of ovine abortion.Distribution of bacteria species and fungi species in aborted dead foeti in sheep and its incidence is represented in Table (2). It is worthy to mention that stomach of aborted ewe foetus harboured all isolated bacteria and fungi from dead aborted foeti and the stomach contents was the most common seat for isolation and considered as the specimens of laboratory choice. It was followed by liver and spleen specimens concerning bacterial isolates, but followed by lung and liver in fungual isolation. While the lungs specimens were the least organs infected by bacteria from examined aborted ewe's foeti, the spleen were the least infected organs by fungi.These findings coincide with the observations obtained by Redman et al., (1963) and Ardrey et al., (1972) who recovered campylobacter spp. mainly from the stomach contents of aborted ovine foetuses followed by the liver specimens, Allsup (1985) noticed that the main best sites for Campylobacter spp. were foetal liver and placenta. While Doghiem et al., (1995) reported that highest isolation of Brucella melitensis was obtained from spleen followed by liver, lungs, lymph node and kidney, Cetinkaya et al., (1999) isolated Brucella melitensis from stomach contents of aborted sheep fetuses by bacteriological isolation and by PCR. Hunter et al., (1976) recorded isolation of salmonella typhimurium from fetal stomach contents and placenta. Low and Renton (1985) who isolated Listeria monocytogens from lung liver spleen and kidney of aborted ewe.

Isolation of Candida albicans from stomach contents of aborted ewe foeti due to the swallowing of the amniotic fluid contaminated with the yeast bodies Smith (1967). Pier et al., (1972) isolated Aspergillus fumigatus from extrauterine organs, placenta and foetal stomach contents. Aspergillus fumigatus penetrates the placenta and infects the foetus by contamination the amniotic fluid, so stomach contents are usually a good source for isolate mycotic agents Miller (1977).

As shown in Table (3), bacteriological and mycological examination of aborted foeti, vaginal discharge and placenta of (50)aborted goats were 32 samples (64\%) positive for bacteriological isolates, while 27 samples (54\%) were positive for mycological isolates. From the bacteriological examination the Brucella melitensis was the most microorganism isolated from aborted goats with the incidence of $20 \%$. They mostly isolated from aborted foeti, placenta and vaginal discharge with the incidence of $(12 \%, 4 \%$ and $4 \%$, respectively), followed by Campylobacter fetus subsp. fetus, Campylobacter fetus subsp. venerealis with the incidence of $10 \%$ and $6 \%$, respectively. They mostly isolated from aborted foeti, placenta and vaginal discharge. Listeria monocytogens, Salmonella typhimurium, Salmonella dublin, Staph. aureus and Escherichia coli were isolated from goat aborted foeti, placenta and vaginal 
discharge with an incidence $10 \%, 8 \%, 4 \%, 4 \%$ and $2 \%$, respectively. These results agreement with El-Nahas (1951), reported brucellosis in goats with an incidence of (21.5\%), Hamdy (1992) ) isolated Brucella melitensis from sheep and goats, Montasser (1999) tested blood serum of goat slaughtered in Cairo abattoir for Brucella was 11.3\% and Hosein et al., (2002) isolated Brucella melitensis from sheep and goats. Campylobacter fetus subsp. fetus isolated in pure culture from the tissues and stomach contents of an aborted foetus of goats Anderson et al., (1983).

Mycological examination of aborted goats shown in table(3) illusterated that Aspergillus fumigatus was the most isolates among Aspergillus species with the incidence of $14 \%$. They mostly isolated from aborted foeti, placenta and vaginal discharge with the incidence of $(8 \%, 2 \%$ and $1 \%$, respectively). It was followed by Candida tropicalis (10\%), Candida albicans (8\%). Then Aspergillus niger, Aspergillus flavus, Mucor spp. Rhizopus spp., Penicillium spp. and Fusarium spp. with the incidence of $(6 \%, 2 \%, 6 \%, 4 \%, 2 \%$ and $2 \%$, respectively from aborted foeti, vaginal discharge and placenta of aborted goats. This results agreement with Osman and Abou-Gabal (1978) who reported the incidence of mycotic infection of goats may reach to $50 \%$ including Aspergillus spp.and Candida spp. Agag et al., (1988) reported the isolation of Fusarium, Cladosporium and Penicillium spp. from mycotic abortion in goats.

Bacteriological and mycological examination of the abomasal contents,liver, spleen and lungs of the goats collected from 50 aborted dead foeti as shown in Table (4), revealed that the stomach contents was the most common seat for the isolation of bacteria and fungi, followed by liver, spleen and lungs specimens for the bacterial isolation, except Brucella melitensis spleen is the second seat followed by liver and lungs. While in mycological isolation the stomach contents followed by lungs, liver and spleen.These results are in accordance with the findings obtained by Prescott and Bruin Mosch (1981) and Andreson et al., (1983) who isolated Campylobacter spp. from stomach contents of goats. The stomach contents are usually a good source for isolation of mycotic agents (Jensen, 1990 and Jensen et al., 1994 ).

As shown in Table(5), most species of Campylobacter fetus subsp. fetus, and Campylobacter fetus subsp. venerealis were highly sensitive to gentamicin, danofloxacin and erythromycin but highly resistant to ampicillin, cephalocin, chloramphenicol,streptomycin and tetracycline. These findings are agreement with that obtained by Zenin (1985) and Narita et al., (1988). While amoxicllin\&clavulanic acid, cephalocin, danofloxacin, penicillin $G$ and chloramphenicol were the most effective anti bacterials on the Listeria monocytogens, these findings are agreement with Braun (2006). Salmonella spp. was sensitive to danofloxacin, gentamicin and chloramphenicol, but Staph. aureus isolates were sensitive to amoxicllin\& clavulanic acid, cephalocin and danofloxacin, while E. coli was sensitive to amoxicllin\& 
clavulanic acid danofloxacin and penicillin G. These agreement with the results of Mishra et al., (1996).

The results in Table (6), summarized the effects of antifungal agents on the Aspergillus fumigatus and Aspergillus flavus were sensitive to clotrimazole, miconazole, and nystatin. While Candida albicans and Candida krusei were highly sensitive to clotrimazole and thibenzole. These results agreement with results obtained by Rippon (1988) and Collee et al., (1996).

The use of polymerase chain reaction (PCR), as shown in Fig. (1), revealed positive amplification of Brucella melitensis on $169 \mathrm{bp}$ and $792 \mathrm{bp}$ fragments on lane 1-2. While lane 3-4 indicates positive amplification of 383bp fragment of Aspergillus fumigatus. These results are in agreement with the results of (Bricker and Halling 1994, Ewalt and Bricker 2000) who used AMOS PCR technique as a diagnostic assay for identification and differentiation of Brucella melitensis from other type of Brucella spp.(Abortus, Melitiensis, Ovis, Suis) . David et al., (2005) recorded that PCR is a useful assay for detection and identifcation Aspergillus fumigatus, also is providing a good alternative to the time consuming isolation test normally used in laboratory routine .

\section{REFERENCES}

Agag, B.I.; Youssef, R.H.; El-Far, F.; Eid, M.A.; Aly, N.M. and Mostafa, A.S. (1988): Serum biochemical changes in relation to mycotic abortion in goats. Assiut Vet. Med. J. 20, (39): 162-167.

Ainsworth, G.C.; and Austwick, P.K.C.(1973) :Fungal disease of Animals . $2^{\text {nd }}$ Edn. Commonweaith Agricultural Bureau. Slough, England.

Allsup, T.N.(1985): Ovine campylobacter abortion. Luxembourg, Commision of the European Communities, 93-107.

Alton,G. G.; Jones, L.M.; and Pietz,D. E. (1975) : Laboratory techniques in brucellosis $2^{\text {nd }}$ ed. FAO/WHO, Geneva.

Anderson, K.; Hamoud, M.; Urbance, J.; Rhoades, H. and Bryner, J. (1983): Isolation of Campylobacter jejuni from an aborted caprine fetus. J.Am. Vet. Med. Asso.,183, (1): 90-92.

Ardrey, W.B.; Armstrong, P.; Minershagen. W. and Frank, F.(1972):

Diagnosis of ovine vibriosis and enzootic abortion of ewes by immunofluorescence technique. Am.J. Vet. Res., 33, (12): 253-258.

Bajmocy, E.; Fazekas, B. and Fodor, L. (1987): Mass outbreak of abortion associated with Campylobacter fetus in sheep flock. Magyar Allatorvosok Lapia . 42, (8) : $467-470$. 
Bircker, B.J. and Halling, S.M. (1994): Differentiation of Brucella abortus (biovars1,2 and 4) Brucella melitensis, Brucella ovis and Brucella suis (biovar1) by the PCR. J. Clin. Microbiol. 32, 2660-2666.

Bird, M.; Stephens, D.; Wall, E. ; and Liste, G.(1984) :Serology of Campylobacter fetus strains from four outbreaks of ovine abortion. New Zealand Vet. J. 32, (1/2) : 14-17.

Braun, U.; Stehle, C. and Ehrensperger, F. (2006): Clinical findings and tretment of listeriosis in 67 sheep and goats. Vet. Rec. 150,(2): 38-42.

Butachaiah, G.; and Khera,S.S. (1982): Studies on bacterial aetiology of in fectious abortion in farm stock . 1-Brucella abortion in cattle, buffaloes, sheep and goats.Indian J.Comparative Microbiol., Immunol. and Infect. Dis.3, (2):83. (Vet. Bull. 1983,Vol. 53, Abs. 2221.).

Carter, G. R.; and Cole, J. R. ( 1990): Diagnostic procedures in Veterinary Bacteriology and Mycology. $5^{\text {th }}$ Ed. Harcourt Brace Jovanovich Publisher New York.

Cetinkaya, B. ; Ongor, H.; Muz, A.; Ertas, H.; Kalender, H. and Erdogan, H.M. (1999): Detection of Brucella species DNA in the stomach content of aborted sheep fetuses by PCR. Vet. Record 27, (144) : 239-240.

Collee, J.G.; Duguid, J.P.; Fraser, A. G.; Marmion, B.P.; and Simmons, A. (1996) : Mackie and McCartney practical Medical Microbiology. $14^{\text {th }}$ ed., Churchill Livingstone, N.Y. London.

Corbel,M. J. (1988): Production of antibodies to placental antigens by pregnant ewes experimentally infected with Aspergillus fumigatus. Br. Vet. J. 128, Xliv-Xlvi.

Cuci,A.(1987): Serological immune response to Aspergillus fumigatus mycosis. Buletini ishkencave Zooteknikee Veterinre 5, 77-83.

David, N. F.; Caitlin, S. and Amalia, M. (2005): Comparison of six DNA extraction methods for recovery of fungal DNA as assessed by quantitative PCR. Clin. Microbiol.J. 43, (10): 5122-5128.

Derbala, A.A. and Ghazi, Y.A. (2001): Some investigations on Brucella and Psoropts mites infection among Barki sheep flock. J. Vet. Med. Res. 3, 173.

Doghiem, R.E.; El-Gibaly, S.; Nafady, A.A.; Moussa, A.A.; Hamoda, M.A. and Montasser, A.M. (1995): Morphopathological and immunopathological 
studies on sheep and goats with brucellosis. $3^{\text {rd }}$ Sci. Cong. Egypt Soc. Cattle Dis., Nov. 1995, Assiut.

El-Nahas, H.M. (1951): Detection of Malta fever in goats in Egypt . M.V.Sc. Thesis, Fac. Vet. Med. Cairo Univ.

Ewalt, D.R. and Bricker, B.J. (2000): Validation of the abbreviated Brucella AMOS PCR as a rapid screening method for differentiation of Brucella abortus field strain isolates and vaccine strains, 19 and RB51. J. Clin. Microbiol. 38, 3085 .

Farid, A.; El-Timawy, A.M.; Serur, B.H.; Farrag, A.A.; Gomaa, A.; Allam, F. and Ibrahim, H.(1986): Microflora of the vagina and external os of ewes during late pregnancy, puerperium and infertile cases. Assiut Vet. Med. J. 17, 177-184.

Finegold, S.M. and Martin , W.J. (1982) : Bailey and Scott's "Diagnostic Microbiology" $6^{\text {th }}$ ed. the C.V. Mosby Co., St., Lowis, Tornoto, London.

Flaat, j.; and Roed, R. (1980): An outbreak of Campylobacter fetus abortions in ewes. Norsk Veterinaetidss Krift. 92, (6) : 391-392.

Hamdy, M.E. (1992):Epidemiological studies on Brucella melitensis in dairy animals . Ph. D. Thesis, Fac. Vet. Med. Cairo Univ.

Hosein, H. I., Dawood, F. Z., and El-Sheary, M.N. (2002): Evaluation of the policy of test and slaughter for control of brucellosis in Egypt. Proc. $10^{\text {th }}$ Sci. Cong. Fac. Vet. Med. Assiut Univ. 350-357.

Hunter, A.G.; Corrigall, W.; Mathieson, A.O. and Scott, J.A. (1976):An outbreak of Salmonella typhimurium in sheep and its consequences. Vet. Rec. 98, (7): 126-130.

Jensen, H.E.(1990): Crossed immuno electrophoresis of fungal antigens in tissues as a mean to diagnosis of systemaic aspergillosis and zygomycosis in cattle. Vet. Res. Commun. 17, 267-272.

Jensen, H.E.; Olsen, S.N. and Aalbaek, B.(1994):Gastrointestinal aspergillosis and zygomycosis of cattle. Vet. Path.. 31, 28-36.

Kholeaf,Z.; Farag, Y.A.; Rakha, A. and Fadle, W.(1977): A preliminary study on the bacteria causing abortion in local sheep. Egypt. J. Vet. Sci., 98 : 700-711. 
Kirkbride, C.A.(1990): Mycotic abortion in cattle. In: Laboratory diagnosis of live stock abortion, (Kirkbride, C.A.,ed.), Iowa State University. Press, Ames. pp.136-152

Knudtson, W.U. and Kirkbride, C.A.(1992): Fungi associated with bovine abortion in the Northern Plains States (USA). J. Vet. Diagn. Invest. 4, 181-185.

Koneman , K. W. ; Allen, S. D . ; Dowell, V. R. and Sommers, H. M. (1992): "Color atlas and text book of diagnostic Microbiology $.2^{\text {nd }}$ ed , J. B. Lippicott Co., London .

Leyla, Guller; Gunduz, K. and Ok, U. (2003): Comparison of polymerase chain reaction and bacteriological culture for the diagnosis of sheep brucellosis using aborted fetus samples. Vet. Microbiol. 93,(2): 53-61.

Liliana de Aguirre,; Steven, F. H.; Jong, H. S.; Hans P. H. and Christine, J. M. (2004): Rapid differentiation of Aspergillus species from other medically important opportunistic molds and yeasts by PCR enzyme immunoassay. Clin. Microbiol. J. 42, (8) : 3495-3504.

Low, J.C. and Renton, C.P. (1985): Septicemia, encephalitis and abortions in a housed flock of sheep caused by Listeria monocytogenes type 1/2 .Vet. Rec.116 (6): 147-150.

Miller, R.B.(1977): A summary of some of the pathogenic mechanisms involved in bovine abortion. Can. Vet. J. 18, (4): 87-95.

Mishra ,K. G. (1992):“ Antimicrobial sensitivity of bacterial isolates from respiratory tract infections of goats of Sikkim.'”nd. J. An.Sci. 62, (7): 635-636.

Montasser, A.M. (1999): Some epidemiological and diagnostic studies on ovine and caprine brucellosis in Egypt. $5^{\text {th }}$ Sci. Cong. Egypt Soc. Cattle Dis., Assiut.

Munoz, M.; Merino, N.; Vieira, S.; Gonzalez, E. and Figuerdo, J.M.(1989): Demonstration of mycotic placentitis in ewes inoculated with Aspergillus fumigatus. Revista de Slaud Animal 11,(1): 25-34.

Narita, M.; Nakamura, H.; Kinjo, T.; Minamoto, N. and Sugiyama, M. (1988): Antimicrobial resistance and plasmid analysis of Campylobacter species isolated from animals. Res. Bull. Fac. Agri. Gifu. Uni., 53: 375-384.

Osman, A.M. and Abou Gabal, M.(1978): Mycotic findings in female genitalia of certain Egyptian ruminants affected with various reproductive disorders. Mycosen 21: (2), 53-58. 
Pal, M. (1988) : Aspergillus niger associated with mycotic abortion in buffalo (Bubalus bubalis ). Mycoses, 31: 17-19.

Pal, M. ; Mathrotra, B.S. ;and Dahiya S.M. (1985) : Studies on mycotic abortion caused by Aspergillus fumigatus Fresenius. Ind. J.Anim.Rep. 6: 43-48.

Pathak, R.C.; and Mittal, K.R. (1966) :Isolation of Aspergillus fumigatus from the cervical mucus of cow having history of metritis. Current Sci. 35 ,312.

Patnaik, N.; Mohanty,N.B. ; Ray, S.K.H.; Mohanty,D.N.; and Mishra, P.R. (1992): Clinical report on lugol's iodine treatment of mycotic abortions in bovine. Indian Vet. J. 69: 1029-1031.

Pier, A.C.; Cysewski, S.J. and Richard, J.L. (1972): Mycotic abortion in ewes produced by Aspergillus fumigatus. Intravascular and intra uterine inoculation. Am. J. Vet. Res. 33:(2), 349-357.

Plagemann, O. (1989) : The most frequent infectious causes of abortion in sheep in north Bavaria with special refrence to Chlamydia and Salmonella infections. Tieraztl Prax 17 (2):145-148.

Prescott, J.F.; and Munroe,D.L.( 1982): Campylobacter jejuni enteritis in man and domestic animals. J.A.V.M.A.,181,(12):1524-1529.

Quinn, P. J. ; Markey , B. K.;Carter, M. E.;Donnelly,W.J. and Leonard, F. C. (2002): Veterinary Microbiology and Microbial Disease. Black well Sc., U.K.

Raper,K.B. and Fennell, D.I. (1965): The genus Aspergillus. Baltimore, Williams and Wikins.

Redkar, R.;Rose ,S.; Bricker, B. ; and Del Vecchio, V.(2001): Real time detection of Brucella abortus, Brucella melitensis and Brucella suis. Mol. Cell. Probes , $15: 43-52$.

Redman, D.; Trapp,A.; Hamdy, A. and Bell, D.(1963): Ovine vibriosis in Ohio. J.Am. Vet. Med. Ass., 143: 1094-1095.

Rippon, J. W.(1988): The pathogenic fungi and the pathogenic actinomycetes. Medical Mycology $3^{\text {rd }}$ ed. (ch8),169. W.B. Saunders Co., Philadelphia.

Sambrook, J.E.F.;Fritsch, E. and Maniatis, T. (1989): Molecular cloning. Lab. Mannal., $2^{\text {nd }}$ ed. Harbor laboratory press. 
Sargison, N.D.; Howie, F.; Thomson, J.R.; Dun, K. and Penny, C.D.(2001): Ovine placentitus and abortion associated with a very toxigenic strains of $E$. coli. Vet. Rec. 149,(23): 711-712.

Saxena,S.C.; and Ishaque, S.M. (1977): Therapeutic evaluation of antimycotic drugs in repeat breeding bovines due to mycotic infection .Current Science 46,780-782

Siddique, I.H.; Grant, G.H.; Blackweli, J.G.;and Mickenzie, B.E. (1976) : Organisms associated with abortions and reproductive problems in cattle. Modern Vet. Practice, 57: 809-811.

Skirrow,m.; and Benjamin, j.(1980): Campylobacters: cultural characteristics of intestinal campylobacters from man and animal. J. Hyg. Comb., 85: 427442.

Smith, J.M.B. (1967): Candidiasis in Animals in New Zaland. Sabouraudia, 5, 220- 225 .

Vandyousefi, D.; and Zoghi, E. (1988) : Mycotic abortions in Iran. Archives de Institut-Razi. 38, 65-71.

Varga,J.(1990): Occurrence and significants of Campylobacter spp. in domastic animals in Hungary. Deut. Tierarztliche Wochenschrift,97, (8): 317 321.

Verma, S.; Katoch, R. C,; Jand, S.K.; and Nigam, P.(1999): Fungi associated with abortions and infertility in does and ewes. Vet. Arhiv 69, 1-5.

Williams, B.M.; Shreeve, B.J.; Hebert, C.N. and Swire, P.W. (1977): Bovine mycotic abortion: Some epidemiological studies. Vet. Rec. 100,382385 .

William, S.P.; Kimmi, N.S.; Nhi,Y.K. ; Susan, L.B.; and Margot ,H.G. (2004) : Real time multiplex PCR assay for detection of Brucella spp. B. abortus, B. melitensis. J.Clin. Microbial., 42 (3): 1290-1293.

Wilson, R.D. and Miles, A. (1975) :Principles of bacteriology , virology and immunity . J.Am. Vet. Med. Ass. $157: 1860$.

Zenin, I.V. (1985): Sensitivity of Campylobacter coli to antibacterial agents. J. App. Bacteriol., 61, (1): 32-38. 
الملخص العربي

\title{
البكتريا والفطريات المصاحبة للأجهاض في الأغنام والماعز في محافظة المنوفية
}

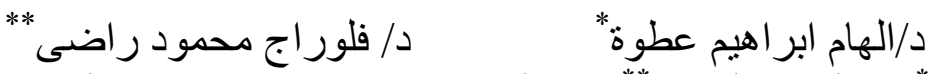 \\ "قسم البكتريولوجى **رقسم الفطريات بمعهد بحوث صحة الحيوان \\ معمل شبين الكوم
}

الأجهاض يعتبر من أهم المشاكل التي تصبب الأغنام والماعز لما يسببه من خسائر اقتصادية كبيرة.

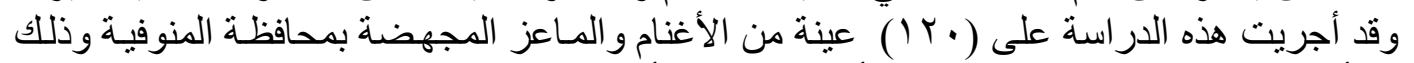

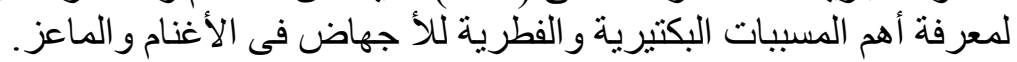

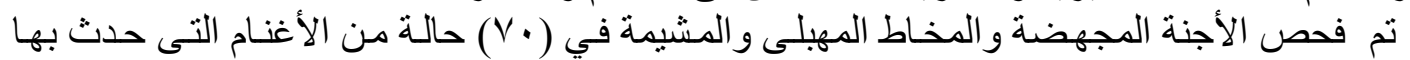

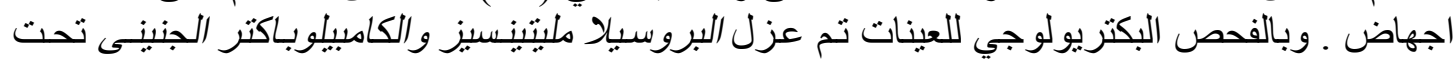

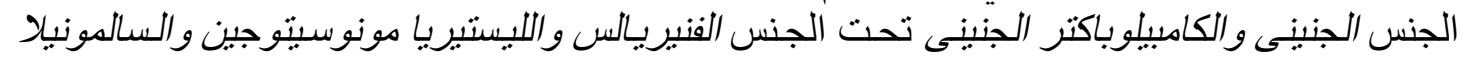

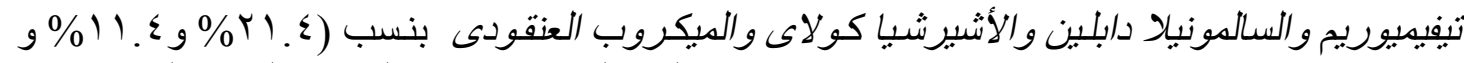

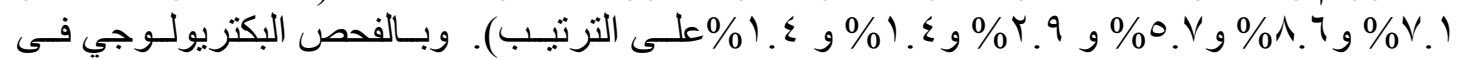

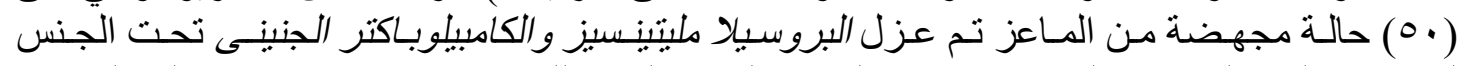

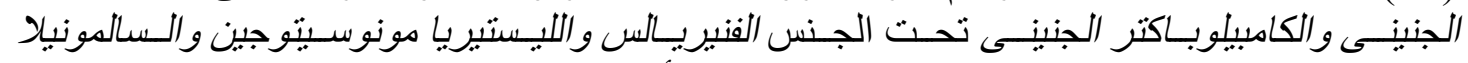

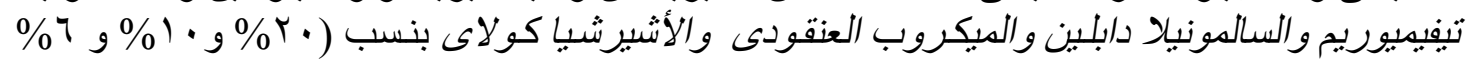

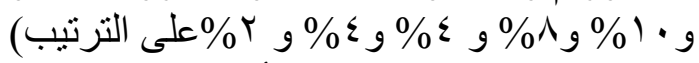

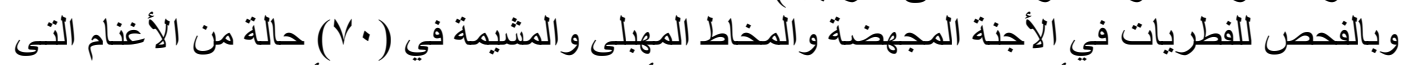

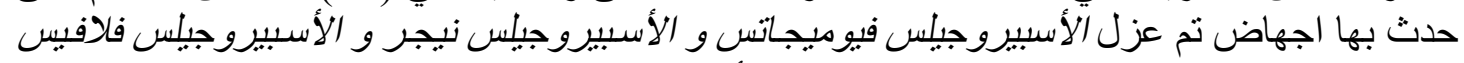

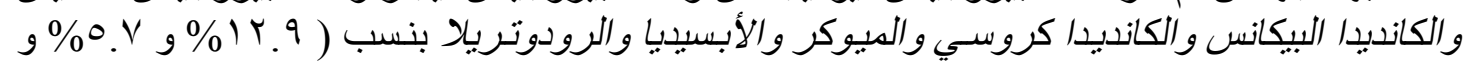

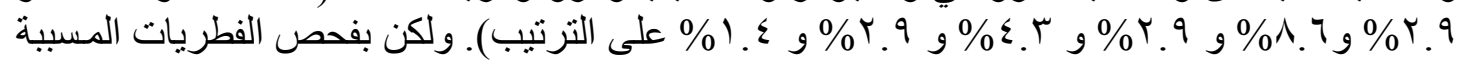

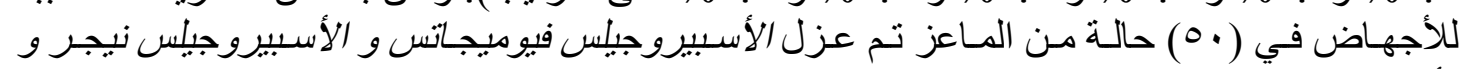

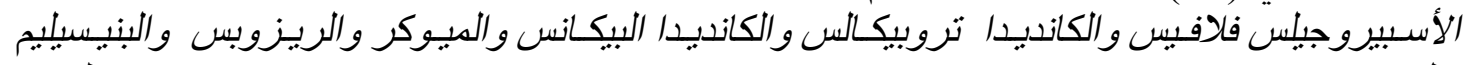

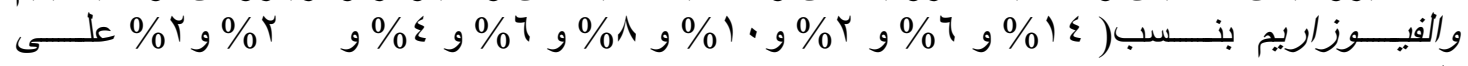
الترنيب). وقد لوحظ أن محتويـات المعدة للأجنـة المجهضة مـن أهم الأمـاكن التي يمكن منهـا عزل البكتيريـا و الفطريات المسببة للأجهاض.

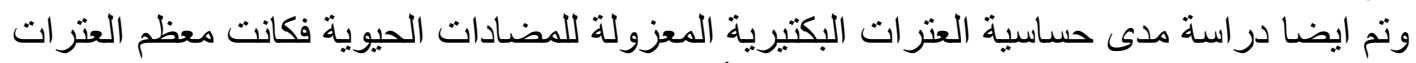

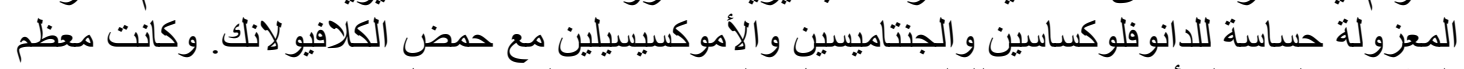

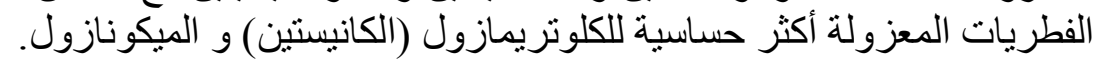

وقد تم أسـتخدام اختبـار تفاعل البلمـرة المتسلسل كطريقـة حديثـة وسـريعة لتشخيص البروسـيلا

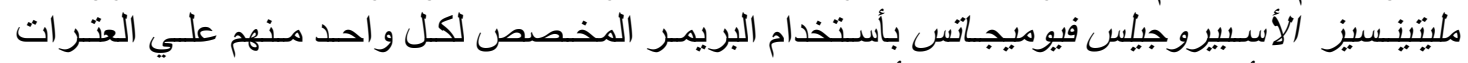

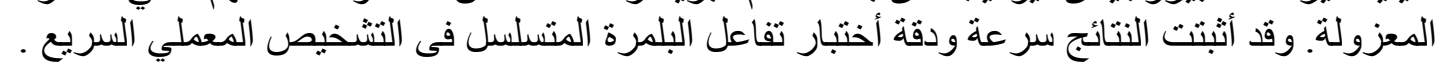

